\title{
Population biology of the sea star Anasterias minuta (Forcipulatida: Asteriidae) threatened by anthropogenic activities in rocky intertidal shores of San Matías Gulf, Patagonia, Argentina
}

\author{
Lorena P. Arribas ${ }^{1 *}$, María Bagur ${ }^{2,4}$, M. Gabriela Palomo ${ }^{2,4}$ \& Gregorio Bigatti ${ }^{1,3}$ \\ 1. Instituto de Biología de Organismos Marinos LARBIM (IBIOMAR-CONICET), Bvd. Brown 2915, U9120ACV, \\ Puerto Madryn, Argentina; arribas@cenpat-conicet.gob.ar; gbigatti@cenpat-conicet.gob.ar \\ 2. Museo Argentino de Ciencias Naturales "Bernardino Rivadavia" (MACN-CONICET), Buenos Aires, Argentina; \\ mbagur@macn.gov.ar; gpalomo@macn.gov.ar \\ 3. UNPSJB. Universidad Nacional de la Patagonia San Juan Bosco, Boulevard Brown 3051, Puerto Madryn, \\ Chubut, Argentina. \\ 4. Grupo de Investigación y Educación en Temas Ambientales (GrIETA), Mar del Plata, Argentina.
}

Received 08-XII-2016. Corrected 09-V-2017. Accepted 20-V-2017.

\begin{abstract}
In Patagonian coastal areas, intertidal benthic communities are exposed to extreme physical conditions. The interaction between harsh environment and anthropogenic pressure can generate changes in population biology of marine invertebrates, like density and reproduction. The oral brooding sea star Anasterias minuta is a key organism in food chains of Atlantic Patagonian rocky intertidals, hence changes on its population structure can negatively affect shore communities. We studied the population biology of $A$. minuta and assess the effect of environmental parameters and anthropogenic activities on its population on rocky intertidal shores of San Matías Gulf, Patagonia, Argentina. Seasonal sea surface temperature, $\mathrm{pH}$, salinity, water velocity, desiccation rate, boulders density, and anthropogenic influence (tourists and octopus fishermen) were recorded. In sites with less tourist influence and high refuge, an increase in density was recorded, especially during the summer. Brooding individuals were found in fall and winter, while feeding individuals were observed in all seasons (12 different prey, mainly the molluscs Tegula patagonica and Perumytilus purpuratus). Environmental variables such as boulders density and water velocity were the most important predictor of variation in population structure. Tourism and $\mathrm{pH}$ were the most important variables negatively correlated with density. Rev. Biol. Trop. 65(Suppl. 1): S73-S84. Epub 2017 November 01.
\end{abstract}

Key words: Asteriidae; physical stress; rocky intertidal; Patagonia; predation; anthropogenic impact.

The oral brooding sea star Anasterias minuta Perrier, 1875 is one of the most conspicuous littoral macro-invertebrate predator in the low-intertidal level in Atlantic Patagonian coasts, which feeds on a wide range of prey, predominantly on the abundant purple mussel Perumytilus purpuratus (Gil \& Zaixso, 2008; Arribas, Martinez \& Brogger, 2016). The sea star A. minuta (possibly a junior synonym of Anasterias antarctica according to Clark \& Downey, 1992, although treated as valid by Hernandez \& Tablado, 1985) does not feed during the brooding period (Gil \& Zaixso,
2007; Pérez, Boy, Calcagno \& Malanga, 2015). Spawning proceeds during March and female broods from May to October (Salvat, 1985) with period extended in some latitudes in relation with interannual variability in temperature (Gil \& Zaixso, 2007). The development of $A$. minuta includes a benthic non-feeding, lecithotrophic, modified brachiolaria that comprises eight distinct stages and a connection cord that holds the brooded larvae together (Gil, Escudero \& Zaixso, 2011). Gonadal maturation occurs in summer in both sexes and show a strategy characteristic of broadcast spawners, 
where females spawn only a small number of eggs (Gil et al., 2011; Pérez et al., 2015).

San Matías Gulf - northernmost Patagonian gulf of Argentinean coast - shows zones with distinct oceanographic parameters: the north and east areas present high temperature, high salinity, and low concentrations of nitrates, while the south and southeast are characterized by lower temperatures and salinities (Gagliardini \& Rivas, 2004). This gulf presents an alternation of warm and cold water depending on the seasons of the year with the contribution of thermophilic organisms during some months (Escofet, Orensanz, Olivier \& Scarabino, 1978; Ramírez, 1996; Arribas et al., 2016). Further, San Matías Gulf sheltered a high number of benthic species (Iribarne, 1990; Morsan, 2009; Morsan, Zaidman, Ocampo-Reinaldo \& Ciocco, 2010; Arribas, Bagur, Klein, Penchaszadeh \& Palomo, 2013) and principally a high biodiversity of echinoderms (Morsan, 2009; Arribas et al. 2016). Organisms in Patagonian intertidal shores are exposed to extreme physical conditions due to strong winds, large tidal amplitude and high temperatures (Bertness et al., 2006; Harley, 2011). Intertidal boulders and cobbles in San Matías Gulf provide refuge from predators and attenuate the physical stress during low tides, therefore providing protection for many species and increasing intertidal biodiversity (Bagur unpubl. data). The sea star A. minuta take refuge almost exclusively under these boulders and cobbles during low tides in rocky intertidals of Patagonia (Gil \& Zaixso, 2008).

In the last twenty years, the coasts of San Matías Gulf became important tourist centres for its seashores and marine fauna (Chomnalez, 2011), added to the anthropogenic activities carried out since the 60's such as octopus and inshore dredge fisheries (Narvarte, González \& Filippo, 2007; Morsan, 2009). Although in San Matías Gulf evidence of marine community changes have been recorded (Narvarte et al., 2007; Morsan, 2009) the ecological effects of fisheries, tourism and industries on benthic communities are not well documented. The interaction between anthropogenic disturbance and extreme environmental conditions can generate changes in density, reproductive outcome, growth and feeding of species (Temara, Warnau, Jangoux \& Dubois, 1997; Dias et al., 2009; Bigatti et al., 2009) and may exceed the natural tolerance threshold (Morsan, 2009). Understanding the variation in the biology of organisms is possible to identify the importance of environmental controls on the population structure and, in turn, anticipate possible consequences of the adverse effects of anthropogenic activities (Harley et al., 2006). In San Matías Gulf, it is common that tourists and octopus fishermen turn around boulders to watch invertebrates, take "souvenirs" or search for edible seafood (e.g., mussels, octopus and fish). However, boulders are not always returned to their original position, possibly affecting the biodiversity (Bagur et al. unpubl. data). The aim of this work was to study the biology of the sea star A. minuta and the effect of anthropogenic influence and environmental conditions on its population in rocky intertidal shores of San Matías Gulf, Patagonia Argentina.

\section{MATERIALS AND METHODS}

Study site: The study was conducted in three rocky intertidal shores near the town of Playas Doradas, south of San Matías Gulf (Fig. 1). The sampled sites were: Playas Doradas $\left(41^{\circ} 38^{\prime} \mathrm{S}\right.$ and $65^{\circ} 1^{\prime} \mathrm{W}$, hereafter PD), Playa Los Suecos $\left(41^{\circ} 40^{\prime} \mathrm{S}\right.$ and $65^{\circ} 1^{\prime} \mathrm{W}$, hereafter PS) and Punta Colorada (41 $42^{\prime} \mathrm{S}$ and $65^{\circ} 1^{\prime}$ $\mathrm{W}$, hereafter PC). These rocky outcrops, apart ca. $3.5 \mathrm{~km}$ between them, belong to a group of volcanic and marine sediments with large pyroclastic contribution (Kokot, Codignotto \& Elissondo, 2004). Moreover, boulders and cobbles are present with different densities at all sites (Table 1). The town houses 194 permanent inhabitants (INDEC, 2010) but the great visitors influence (mainly recreation and octopus fisheries) can rise up to 80,000 in the summer season (information provided by Secretary of Tourism of Sierra Grande, 2017). During the summer less than $1 \%$ of tourists go to PC and only the $9 \%$ to PS, remaining 


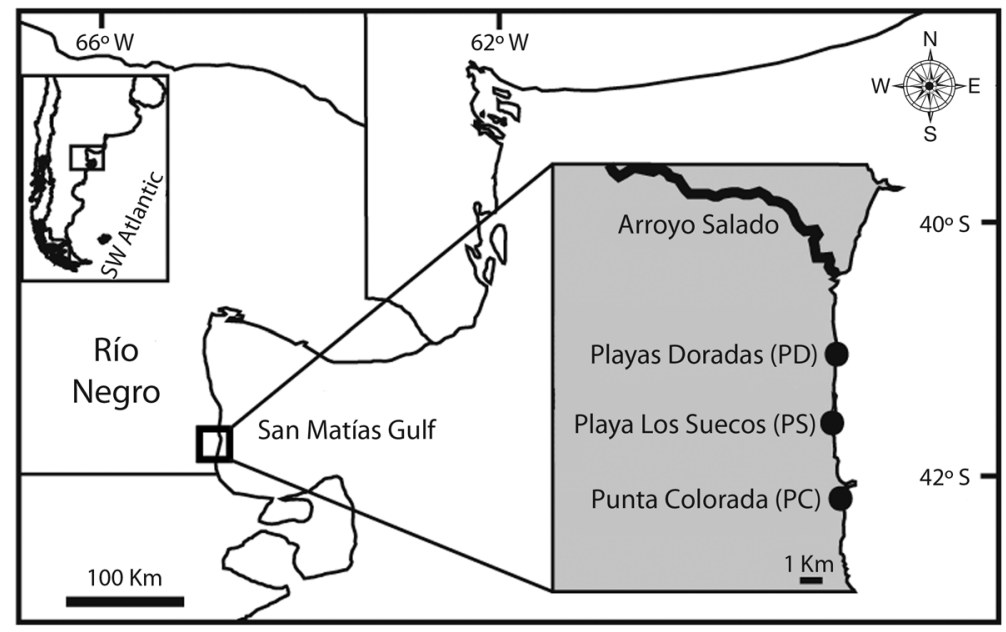

Fig. 1. Sampling sites at three wave-exposed rocky shore intertidal $(\mathrm{PD}=$ Playas Doradas, PS = Playa Los Suecos, and PC = Punta Colorada) surveyed in San Matías Gulf, Argentina, on the SW Atlantic coast.

Fig. 1. Sitios de muestreo en tres intermareales rocosos expuestos $(\mathrm{PD}=$ Playas Doradas, PS $=$ Playa Los Suecos, y PC $=$ Punta Colorada), localizadas en el Golfo San Matías, Argentina, en el suroeste de la costa Atlántica.

TABLE 1

Average boulders density and physico-chemical characteristics measured as annual mean (SD) in the three study sites

CUADRO 1

Promedio anual (DS) de la densidad de las rocas y características físico-químicas en los tres sitios de estudio

\begin{tabular}{|c|c|c|c|c|}
\hline Variable & $\mathrm{PD}$ & PS & $\mathrm{PC}$ & Description \\
\hline Boulders & $9(6.46)$ & $17(4.90)$ & $27.5(11.24)$ & $\begin{array}{l}\text { Boulders and cobbles (rocks } \mathrm{m}^{-2} \text { ) quantified in ten } \\
50 \times 50 \mathrm{~cm} \text { quadrats. }\end{array}$ \\
\hline Temperature & $15.85(2.91)$ & $15.38(2.73)$ & $15.17(3.02)$ & $\begin{array}{l}\text { Sea surface temperature }\left({ }^{\circ} \mathrm{C}\right) \text { quantified with a field } \\
\text { alcohol thermometer nearshore. }\end{array}$ \\
\hline $\mathrm{pH}$ & $7.55(0.17)$ & $7.58(0.18)$ & $7.59(0.15)$ & $\begin{array}{l}\text { Values of } \mathrm{pH} \text { were measured nearshore with } \\
\mathrm{pH} \text { meter/mv - RS232 equipment. }\end{array}$ \\
\hline Salinity & $35.75(0.52)$ & $35.73(0.13)$ & $35.56(0.43)$ & $\begin{array}{l}\text { Salinity (psu) measured with optical refractometer } \\
\text { nearshore. }\end{array}$ \\
\hline Water velocity & $5.69(0.54)$ & $6.36(0.66)$ & $5.41(0.37)$ & $\begin{array}{l}\text { Velocity }\left(\mathrm{m} \mathrm{s}^{-1}\right) \text { quantified by } 5 \text { dynamometers, } \\
k=2 \mathrm{~N} \mathrm{~mm}^{-1} \text {, following Bell \& Denny (1994). }\end{array}$ \\
\hline Desiccation rate $(\%)$ & $3.76(3.24)$ & $4.62(3.27)$ & $5.37(2.95)$ & $\begin{array}{l}5 \text { weighted sponges, water saturated of } 5 \times 2 \times 2 \mathrm{~cm} \text {, } \\
\text { following Bertness et al. (2006). }\end{array}$ \\
\hline
\end{tabular}

PD = Playas Doradas, PS = Playa Los Suecos, PC = Punta Colorada.

almost $90 \%$ at PD beach. On the other hand, octopus fishermen can be found mainly at PC, and in less quantity at PS. Northward of Playas Doradas the temporary creek Arroyo El Salado flows according to low local rainfall of $214.5 \mathrm{~mm} /$ year (predominant during fall season). Southward, a one kilometre length ore wharf distributes iron from Sierra Grande Mine (MCC S.A.) to the dock of Punta Colorada, where a 1500 meters conveyor belt can load ships with a maximum of 2000 tons per hour. Average iron level in gonads of the sea star $A$. minuta in the area was $49.8( \pm 1.24)$ ppm (Arribas et al., unpublished data). 
Sampling design: To describe the physico-chemical conditions at the study sites we quantified seasonally sea surface temperature, $\mathrm{pH}$, salinity, water velocity, desiccation rate and boulders density. Annual mean variations in physico-chemical conditions across sites are shown in Table 1 and to calculate the differences of physico-chemical conditions among sites a one-way analysis of variance (ANOVA) was applied.

To evaluate the density (ind $\mathrm{m}^{-2}$ ), biomass $\left( \pm 0.1, \mathrm{~g} \mathrm{~m}^{-2}\right)$, size (measured as the longest arm length $\mathrm{R}$ with Vernier callipers \pm 0.01 $\mathrm{mm}$ ), incubation period and feeding activity of the sea star Anasterias minuta, seven transect of $10 \mathrm{~m}$ long and $2 \mathrm{~m}$ wide were performed in the low-intertidal level of each site during the four seasons (autumn, winter, spring and summer). All boulders and cobbles inside transects were turn around to search for sea stars (and then put in the right position). Moreover, sea stars with abnormal characteristic (arm number different to five, fused arms, regenerating or broken arms) were recorded.

Multiple linear regression analysis was performed to identify which factors - i.e., anthropogenic or environmental - best predict differences in the observed density and biomass of $A$. minuta. Potential environmental predictor variables included sea surface temperature, $\mathrm{pH}$, salinity, water velocity, desiccation rate and boulders, while anthropogenic variables comprised tourists and octopus fishermen. Tourists and octopus fishermen were treated as semiquantiative variables with three levels each ( $1 \%, 9 \%$ and $90 \%)$.

The indirectly assessed of tourism effect over density and biomass of A. minuta was analysed with a two-way univariate ANOVA. Tourist influence to the different beaches was used as fixed factor (1\% PC, $9 \%$ PS and 90 $\%$ PD) and seasons random and orthogonal to tourist influence (autumn, winter, spring and summer). To achieve ANOVA assumptions a $\ln (\mathrm{x}+1)$ transformation was applied to sea star density and sqrt $(x+1)$ to biomass. To evaluate different factors affecting the density of A. minuta, Generalized Linear Mixed Model
(GLMM) was applied. Density of A. minuta was evaluated by GLMM with Gaussian distribution. Density values were log transformed $[\ln (\mathrm{x}+1)]$ to achieve homogeneity and normality assumptions. Different models were used to test this variable with regard to the following explanatory variables: tourist influence, seasons, sea surface temperature, $\mathrm{pH}$, salinity, water velocity, desiccation rate, octopus fishermen and boulders density. Collinearity explanatory variables were removed from the "full model" (Zuur, Ieno, Walker, Saveliev \& Smith, 2009). In the final (reduced) full model, we included the parameters tourist influence, seasons, $\mathrm{pH}$, salinity, desiccation rate and octopus fishermen. The Akaike information criterion (AIC) was used to determine the best model for the analysed data set. Model selection was performed with an Information Theory (IT) approach using Akaike's information criterion (AIC) and Model averaging (Grueber, Nakagawa, Laws \& Jamieson, 2011). For each data set, the models were ranked by their Akaike weights (wi) values; the model with the highest wi was considered the one with the best supporting data and model averaging was calculated using candidate models, which together account for the $95 \%$ confidence level. The top model set was averaged using the $95 \%$ confidence set (Burnham \& Anderson, 2002), where the best AIC model was not strongly weighted.

Sea star size were pooled (from the seven transects) for each site and season, so that size class distribution could be assessed visually. Chi-square tests were done to compare the number of $A$. minuta individuals in each size class at the three sites in the four seasons.

To analyse the reproduction period, the relative abundances of brooding $A$. minuta individuals at the three sites sampled was evaluated by Kruskal-Wallis ANOVA tests. The relative abundances of abnormal $A$. minuta characteristic in sampled transects was analysed among sites as described above for brooding individuals in the one year sampled, as well as for relative abundances of $A$. minuta individuals feeding. 


\section{RESULTS}

Some environmental variables showed significant differences among sites. Values of $\mathrm{pH}$ presented significant differences among sites (lower $\mathrm{pH}$ value at PD than at the other sites; $\mathrm{F}_{2,33}=7.4, \mathrm{P}<0.01$ ), as well as water velocity (higher water velocity at PS than at PC; $\left.\mathrm{F}_{2,57}=4.4, \mathrm{P}<0.05\right)$ and boulders density (higher boulders density at $\mathrm{PC}$ than at the other sites; $\left.F_{2,29}=14.60, \mathrm{P}<0.001\right)$. Sea surface temperature, salinity and desiccation rate did not show differences among sites $\left(\mathrm{F}_{2,33}=0.21, \mathrm{~F}_{2,33}=1.10\right.$, and $\mathrm{F}_{2,57}=0.75$, $\mathrm{P}>0.05$ respectively).

The sea star Anasterias minuta was found under boulders and cobbles in the low-intertidal level at all sites and seasons sampled. The multiple lineal regression analysis explained the relationship in the density and biomass of A. minuta with environmental and anthropogenic variables. Boulders density and octopus fishermen were the most important predictor of A. minuta density, although only the first variable was statistically significant $\left(\mathrm{F}_{8.75}=9.73\right.$, $\left.\mathrm{R}^{2}=0.51, \mathrm{P}<0.0001\right)$. Water velocity and sea surface temperature were the two predictor variables most important of $A$. minuta biomass being only water velocity statistically

\section{TABLE 2}

Two-way ANOVA testing factors governing Anasterias minuta density (ind $\mathrm{m}^{-2}$ ) and biomass $\left(\mathrm{g} \mathrm{m}^{-2}\right)$ at the three sites in the four sampled seasons

CUADRO 2

ANOVA de dos vías con los factores de prueba de la densidad (ind $\mathrm{m}^{-2}$ ) y biomasa $\left(\mathrm{g} \mathrm{m}^{-2}\right)$ de Anasterias minuta en los tres sitios y en las cuatro estaciones muestreadas

\begin{tabular}{lccccc} 
& \multicolumn{4}{c}{$\begin{array}{c}\text { Anasterias minuta } \\
\text { density }\end{array}$} & \multicolumn{2}{c}{$\begin{array}{c}\text { Anasterias minuta } \\
\text { biomass }\end{array}$} \\
& df & MS & F & MS & F \\
Sites & 2 & 12.10 & $19.80^{* *}$ & 0.15 & 2.89 \\
Seasons & 3 & 3.21 & $5.25^{*}$ & 0.16 & 3.17 \\
Sit. x Seas. & 6 & 0.61 & 1.90 & 0.05 & 1.02 \\
Residual & 72 & 0.32 & & 0.05 & \\
\hline
\end{tabular}

Ln $(\mathrm{x}+1)$ was applied to $A$. minuta density and Sqrt $(\mathrm{x}+1)$ transformation to A. minuta biomass to achieved ANOVA assumptions. $* \mathrm{P}<0.05, * * \mathrm{P}<0.001$. significant $\left(\mathrm{F}_{8,75}=1.80, \mathrm{R}^{2}=0.16, \mathrm{P}<0.09\right)$. In both analyses significant regression coefficients were positive.

Average density of $A$. minuta varied from 0.31 to 2.41 ind $\mathrm{m}^{-2}$. In summer season, density at $\mathrm{PC}$ was almost $250 \%$ and $500 \%$ higher than at PS and PD respectively. A significantly increase in $A$. minuta density was observed from PD to PS and PC (Table 2, Fig. 2A). The highest density was found during austral summer and the lowest during spring (Fig. 2B). Biomass of A. minuta ranged from 0.14 to $0.24 \mathrm{~g} \mathrm{~m}^{-2}$ with no significant differences among sites or seasons (Table 2, Fig. 3). The density of $A$. minuta was studied as a function of explanatory variables (GLMM). The full model considered five fixed effects and one random
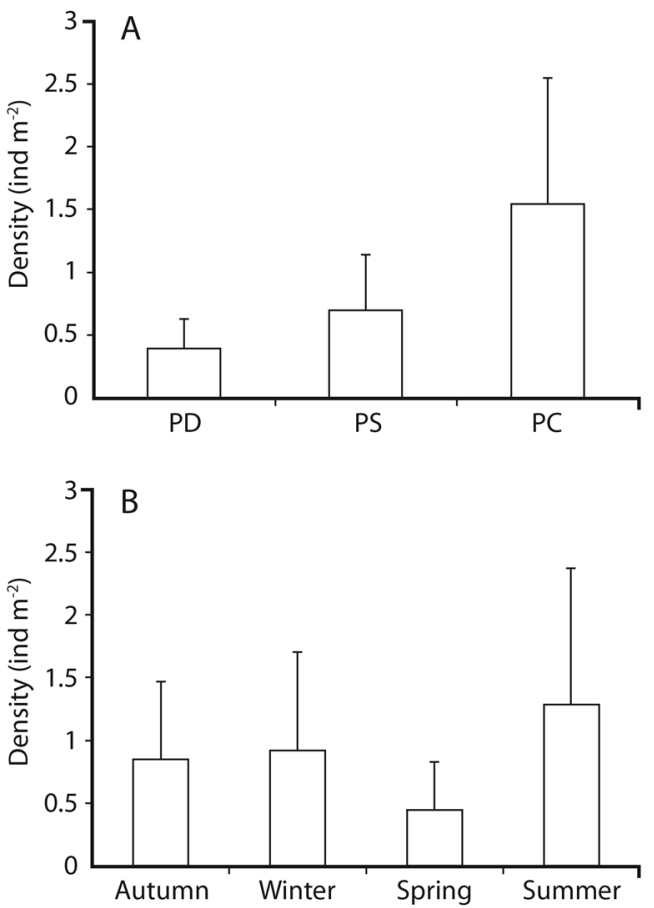

Fig. 2. Anasterias minuta mean density (ind $\mathrm{m}^{-2} \pm \mathrm{SD}$ ) A. at the three sites sampled Playas Doradas (PD), Playa Los Suecos (PS), and Punta Colorada (PC); and B. at the four seasons sampled (autumn, winter, spring and summer).

Fig. 2. Densidad promedio (ind $\mathrm{m}^{-2} \pm \mathrm{SD}$ ) de Anasterias minuta. A. En los tres sitios de muestreo, Playas Doradas (PD), Playa Los Suecos (PS) y Punta Colorada (PC); y B. En las cuatro estaciones muestreadas (otoño, invierno, primavera y verano). 


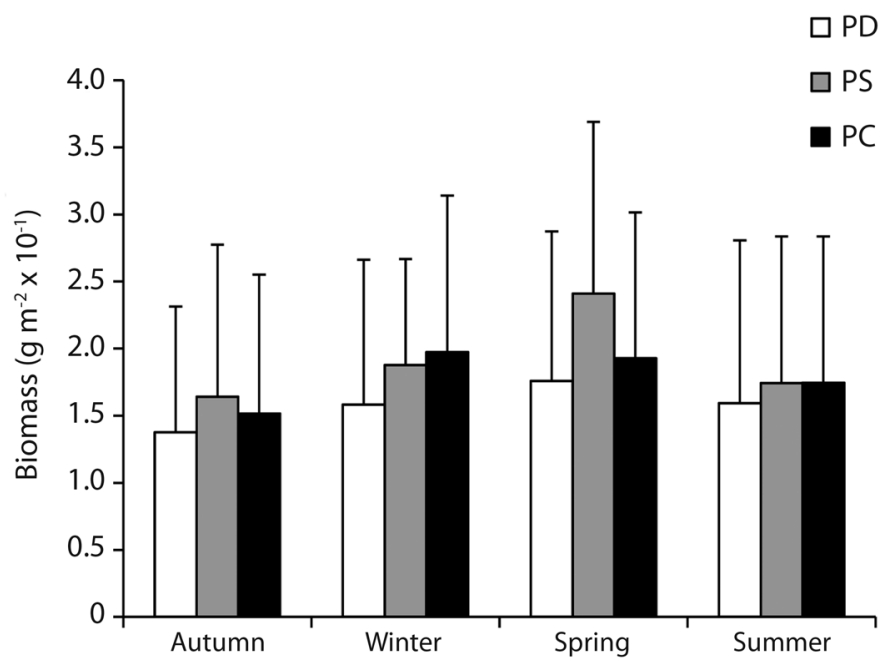

Fig. 3. Mean biomass $\left(\mathrm{g} \mathrm{m}^{-2} \times 10^{-1}\right)$ of Anasterias minuta at the three sites sampled during the four seasons (autumn, winter, spring and summer). Playas Doradas (PD), Playa Los Suecos (PS), and Punta Colorada (PC).

Fig. 3. Biomasa promedio $\left(\mathrm{g} \mathrm{m}^{-2} \times 10^{-1}\right)$ de Anasterias minuta en los tres sitios de muestreo durante las cuatro estaciones (otoño, invierno, primavera y verano). Playas Doradas (PD), Playa Los Suecos (PS) y Punta Colorada (PC).

among the explanatory variables (tourist influence, desiccation rate, $\mathrm{pH}$, salinity, octopus fishermen and seasons respectively). Thirtytwo candidate models were compared. The model with the highest weight was the model involved tourist influence, desiccation rate, $\mathrm{pH}$ and seasons $(\mathrm{w}=0.27)$, and an averaged model involved ten candidate models which together account for the $95 \%$ confidence level. The factors tourist influence and $\mathrm{pH}$ had a greater relative importance than desiccation rate, octopus fishermen and salinity (Table 3 ). The most important variable was tourist influence $(100 \%)$ following by $\mathrm{pH}(94 \%)$, and the less important salinity (31\%).

The arm length of $A$. minuta ranged from 4 to $37.5 \mathrm{~mm}$. The widest size range of $A$. minuta was observed at PS. The number of individuals in each size class was different among sites and seasons (Table 4, Fig. 4). The lowest size range was found at PD in all seasons sampled. Similar individual sizes distribution were presented

TABLE 3

Summary results after model averaging: effect of each variable on Anasterias minuta density

\section{CUADRO 3}

Resumen de los resultados del promedio del modelo: efecto de cada variable en la densidad de Anasterias minuta

\begin{tabular}{lccccc}
\multicolumn{1}{c}{ Parameter } & Coefficient & Adjusted SE & \multicolumn{2}{c}{ Confidential interval } & Relative importance \\
(Intercept) & 17.508 & 12.773 & -7.526 & 42.542 & - \\
Desiccation rate & 0.044 & 0.049 & -0.009 & 0.161 & 0.59 \\
pH & -1.984 & 0.908 & -3.629 & -0.611 & 0.94 \\
Site PD & -1.251 & 0.174 & -1.592 & -0.909 & 1.0 \\
Site PS & -0.714 & 0.170 & -1.048 & -0.380 & 1.0 \\
Octopus fishermen & 0.003 & 0.004 & -0.001 & 0.012 & 0.55 \\
Salinity & 0.057 & 0.217 & -0.517 & 0.891 & 0.31 \\
\hline
\end{tabular}


TABLE 4

Chi-square test results for differences in the number of individuals of Anasterias minuta in each size class at the three study sites in the four seasons

\section{CUADRO 4}

Resultados de la prueba Chi-Cuadrado de las diferencias en el número de individuos de Anasterias minuta en cada clase de tallas en los tres sitios de estudio, en las cuatro estaciones climáticas

\begin{tabular}{|c|c|c|c|c|c|c|}
\hline \multirow{2}{*}{$\begin{array}{c}\text { Anasterias minuta size } \\
\text { (season comparison) }\end{array}$} & \multicolumn{2}{|c|}{ PD-PS } & \multicolumn{2}{|c|}{ PD-PC } & \multicolumn{2}{|c|}{ PS-PC } \\
\hline & df & $\chi^{2}$ & $\mathrm{df}$ & $\chi^{2}$ & df & $\chi^{2}$ \\
\hline Autumn & 32 & 197.34 & 32 & 132.60 & 68 & 289.60 \\
\hline Winter & 51 & 1100.58 & 51 & 162.97 & 129 & 287.49 \\
\hline Spring & 42 & 292.95 & 42 & 121.49 & 43 & 197.22 \\
\hline Summer & 67 & 166.18 & 67 & 213.78 & 135 & 414.28 \\
\hline
\end{tabular}

$\mathrm{PD}=$ Playas Doradas, PS $=$ Playa Los Suecos, $\mathrm{PC}=$ Punta Colorada. In all cases $\mathrm{P}<0.001$.

at PS and PC during autumn and spring. Higher size was showed at PC than at PS in winter and an opposite pattern during summer.

Individuals of $A$. minuta were found brooding during austral fall and winter at all study intertidal sites. Relative abundances of A. minuta brooding were not significantly different among sites (Kruskal-Wallis $=2.97$, $\mathrm{P}=0.23$ ). We found $A$. minuta individuals with four and six arms, besides open aboral arms, in regeneration period and fused arms. Relative abundances of $A$. minuta with these abnormal characteristics in sampled transect showed differences among sites (Kruskal-Wallis $=6.72$, $\mathrm{P}=0.035$ ). PS was the site with the highest values of abnormal characteristics followed by PC. The sea star $A$. minuta was found feeding in all sampled seasons, recording a total of 12 different preys. No brooding sea stars were observed feeding during incubation period. The most abundant prey was the gastropod Tegula patagonica (43.75\%) followed by the bivalve Perumytilus purpuratus (16.62\%). Other common prey found were the bivalve Brachidontes rodriguezii (6.25\%), the limpet Fissurella radiosa $(6.25 \%)$, and the chiton Plaxiphora aurata $(6.25 \%)$. Relative abundances of $A$. minuta feeding did not show differences among sites (Kruskal-Wallis $=0.30, \mathrm{P}=0.86$ ).

\section{DISCUSSION}

Density of Anasterias minuta increased in sites further away from the most touristic crowded places (i.e., PC), and accordingly the differences were more pronounced during summer time in the beaches more visited by tourist (people density is 400 times higher than local population). In addition, higher amount of boulders and cobbles generates differences in the density of $A$. minuta, since they take refuge under rocks avoiding desiccation and extreme environmental conditions during low tides. Previous works on temporary aggregative behaviour in echinoderms have recorded that maximum aggregation typically occurred just before and during the spawning period, improving spawning synchrony and/or increase gamete encounter probabilities (Young, Tyler, Cameron \& Rumrill, 1992; Hamel \& Mercier, 1995; Mercier \& Hamel, 2008). The highest A. minuta density registered during summer, when gonadal maturation occurs in both sexes (Pérez et al., 2015), could be a consequence of this reproductive aggregation pattern observed previously in echinoderms in relation with reproductive success. In addition, the lowest density was found during the non-reproductive season (i.e., spring) when gonads are immature (Gil et al., 2011; Pérez et al., 2015). 

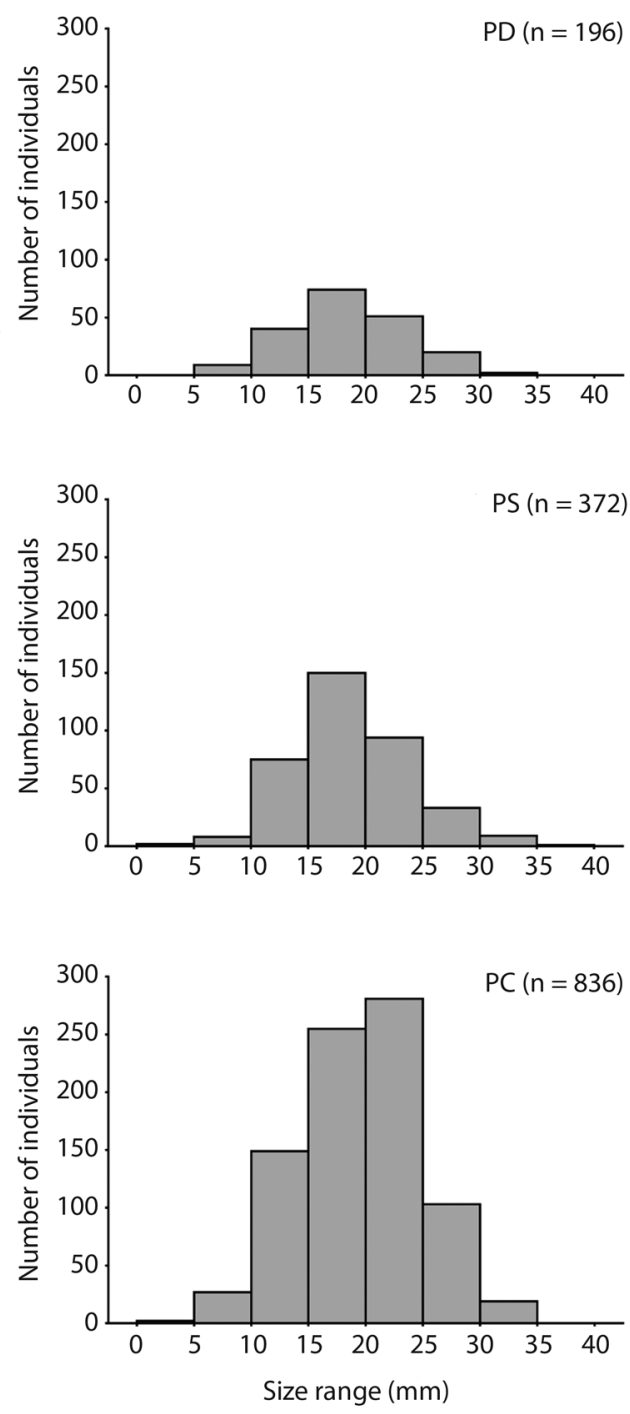

Fig. 4. Number of individuals in each size class for Anasterias minuta populations at the three study sites (seasons pooled per sites), showing sample size (n). Playas Doradas (PD), Playa Los Suecos (PS), and Punta Colorada (PC).

Fig. 4. Número de individuos en cada clase de tallas para la población de Anasterias minuta en los tres sitios de estudio (estaciones climáticas agrupados por sitios), mostrando el tamaño de muestra (n). Playas Doradas (PD), Playa Los Suecos (PS) y Punta Colorada (PC).

On exposed shores, the broad water exchange with the open ocean enhances the influx food and larvae supply to intertidal habitats favouring the increase in invertebrate species (Gaines \& Bertness, 1993; Bertness et al., 2006; Arribas, Donnarumma, Palomo \& Scrosati, 2014). San Matías Gulf communicates through a broad mouth with the open ocean and tides dominate gulf dynamics (Moreira, Simionato, Dragani \& Nuñez, 2009) with water velocity values similar to a previous work in Patagonia exposed shores (see Bertness et al., 2006). Water velocity can be regulating the amount and quality of available food (Feder, 1970; Cahalan, Siddall \& Luckenbach, 1989; Freeman, Richardson \& Seed, 2001) generating as consequence the significant relationship of this variable with the increase of $A$. minuta biomass as was observed in our results. Further, sea stars are capable of rapid increase in size if food is abundant and conditions are favourable for feeding (Feder, 1970; Tokeshi, Estrella \& Paredes, 1989; Lawrence, 2010). Sea stars can be mainly dependent of invertebrate abundances, sizes and also the nature of the food (i.e., populations associated with high density of one prey species or with mixed diet; Larsson, 1968; Feder, 1970; Tokeshi et al., 1989). Moreover, sea stars tend to be larger where they are less abundant due to increase in food availability (Smith, 1940). Sea stars fed over a mixed variety of prey at PD where, meanwhile the main prey consumed were the herbivorous gastropod Tegula patagonica and the mussel Perumytilus purpuratus at PS and PC. Differences found in our results can be associated with nature of food since high densities of sea stars seem not to affect size the on populations. However, nutrient allocation studies related with different diets are needed to support this size variation. Therefore, water velocity and a potential difference in consumed prey can have influence on A. minuta population structure.

Two facts that can contribute to the observed abnormal characteristics in the sea stars morphology are the artisanal wire hook technique used to remove the abundant intertidal octopus Octopus tehuelchus (Iribarne, 1990) and/or the iron distribution pier situated at PC. Increase in abnormalities was observed mainly at PC and PS according with the increase in octopus fishermen and nearness 
to $\mathrm{PC}$ pier. Moreover, iron levels were found in gonads of the sea star A. minuta and some authors related it to high metabolic activity of this organ (Flammang, Warnau, Temara, Lane \& Jangoux, 1997), while the increased iron levels in the surrounding environment may affect the normal physiology of echinoderms (Trieff et al., 1995; Flammang et al., 1997; Temara et al., 1997; Kobayashi \& Okamura, 2005). Biomass of $A$. minuta did not show significantly differences among sites, although the highest sea stars densities were observed at PC and PS, and both sites presented largest sizes than PD. High iron concentrations can affect aquatic invertebrates' biomass, where animals become more inactive and stopped food consumption (Gerhardt, 1992). Future laboratory and field experiments are needed to quantify the effect of some of these potentially harmful anthropogenic activities on A. minuta populations.

Increasing atmospheric $\mathrm{CO}_{2}$ concentrations are predicted to decrease ocean $\mathrm{pH}$, with potentially impacts on marine organisms, especially calcareous species (Wootton, Pfister \& Forester, 2008; Dupont, Martínez \& Thorndyke, 2010). This decline can be able to generate in the long term changes on sea stars reproduction, biomass or growth, having ecological consequences at specific level and for near shore benthic ecosystems (Atkinson \& Cuet, 2008; Dupont et al., 2010). Population structure of $A$. minuta seems to be more affected by tourist influence and $\mathrm{pH}$ levels, therefore changes predicted by the Intergovernmental Panel on Climate Change (IPCC, Collins et al., 2013) must be taking into account to analyse and pay attention to sea stars structuring role in this habitat (Saier, 2001; Mercier \& Hamel, 2009; Keppel, Scrosati \& Courtenay, 2015). Particularly, A. minuta consume the mussel $P$. purpuratus, an ecosystem engineer that creates habitat for a high number of species (Jones, Lawton \& Shachak, 1994; Arribas et al., 2013), of which some could be exclusively found in this habitat (Bagur, Gutiérrez, Arribas \& Palomo, 2016). Whereby, alterations of $A$. minuta populations could affect the whole community and threaten the equilibrium of the ecosystem where they live (Paine, 1966; Navarrete \& Castilla, 2003). Given the great diversity of prey ingested by $A$. minuta and its role as top predator on intertidal rocky shore, future changes in the population structure of the sea star could affect biodiversity throughout the North Patagonian coasts.

\section{ACKNOWLEDGMENTS}

We thank Rocío Nieto Vilela, Clara Giachetti and Nicolás Battini for help in field work, Carmen Gilardoni and Virginia Alonso Roldán for their help in statistical analyses, and Sofía Quiroga for housing during field trips. This is the contribution $\mathrm{N}^{\circ} 88$ of the Laboratorio de Reproducción y Biología Integrativa de Invertebrados Marinos (LARBIM). The research presented here was partly funded by CONICET (Consejo Nacional de Investigaciones Científicas y Técnicas, Argentina; PIP 0024 to MGP, PICT 2709 to GB, PICT 0249 to LPA, and PICT 2929 to Averbuj Andrés). LPA and $\mathrm{MB}$ were supported by CONICET postdoctoral fellowships. This is a contribution to the program of GrIETA. This manuscript was substantially improved by comments from José Carlos Hernández and an anonymous reviewer.

\section{RESUMEN}

Biología poblacional de la estrella del mar Anasterias minuta (Forcipulatida: Asteriidae) amenazada por actividades antropogénicas en las costas rocosas intermareales del Golfo de San Matías, Patagonia, Argentina. En las áreas costeras Patagónicas, las comunidades intermareales bénticas están expuestas a condiciones físicas extremas. La interacción entre un duro ambiente y la presión antrópica pueden generar cambios en la biología de las poblaciones de invertebrados marinos, como la densidad y la reproducción. La estrella de mar incubadora oral Anasterias minuta es un organismo clave en las cadenas alimenticias de los fondos rocosos intermareales del Atlántico Patagónico, por lo tanto, cambios en la estructura de sus poblaciones pueden afectar negativamente las comunidades costeras. Nosotros estudiados la biología poblacional de $A$. minuta y evaluamos el efecto de los parámetros ambientales y actividades antropogénicas en las poblaciones de las costas rocosas intermaeales del Golfo de San Matías, Patagonia, Argentina. Temperatura estacional superficial del mar, $\mathrm{pH}$, salinidad, velocidad del agua, tasa 
de desecación, densidad de cantos e influencia antropogénica (turismo y pesca de pulpos) fueron documentados. En sitios con menor influencia turística y mayores refugios, un incremento en la densidad fue documentado, especialmente durante el verano. Individuos incubadores fueron encontrados en otoño e invierno, mientras individuos alimentándose fueron observados en todas las estaciones (12 presas diferentes, principalmente los moluscos Tegula patagonica y Perumytilus purpuratus). Variables ambientales tales como densidad de cantos y velocidad del agua fueron los más importantes predictores de la variación de la estructura poblacional. Turismo y $\mathrm{pH}$ fueron las variables más importantes correlacionadas negativamente con la densidad.

Palabras clave: Asteriidae; estrés físico; intermareal rocoso; Patagonia; depredación; impacto antrópico.

\section{REFERENCES}

Arribas, L. P., Bagur, M., Klein, E., Penchaszadeh, P., \& Palomo, M. G. (2013). Geographic distribution of two mussel species and associated assemblages along the northern Argentinean coast. Aquatic Biology, $18,91-103$.

Arribas, L. P., Donnarumma, L., Palomo, M. G., \& Scrosati, R. A. (2014). Intertidal mussels as ecosystem engineers: their associated invertebrate biodiversity under contrasting wave exposures. Marine Biodiversity, 44(2), 203-211.

Arribas, L. P., Martinez, M. I., \& Brogger, M. I. (2016). Echinoderms in San Matías Gulf, Southwestern Atlantic Ocean. Thalassas, 32, 11-18.

Atkinson, M. J., \& Cuet, P. (2008). Possible effects of ocean acidification on coral reef biogeochemistry: topics for research. Marine Ecology Progress Series, $373,249-256$.

Bagur, M., Gutiérrez, J. L., Arribas, L. P., \& Palomo M. G. (2016). Complementary influences of co-occurring physical ecosystem engineers on species richness: insights from a Patagonian rocky shore. Biodiversity and Conservation, 25, 2787-2802.

Bell, E. C., \& Denny, M. W. (1994). Quantifying "wave exposure": a simple device for recording maximum velocity and results of its use at several field sites. Journal of Experimental Marine Biology and Ecology, 181, 9-29.

Bertness, M. D., Crain, C. M., Silliman, B. R., Bazterrica, M. C., Reyna, M. V., Hidalgo, F., \& Kongo Farina, J. (2006). The community structure of western Atlantic Patagonian rocky shores. Ecological Monographs, 76(3), 439-460.

Bigatti, G., Primost, M. A., Cledón, M., Averbuj, A., Theobald, N., Gerwinski, W., Arntz, W., Morriconi, E., \& Penchaszadeh, P. E. (2009). Biomonitoring of TBT contamination and imposex incidence along $4700 \mathrm{~km}$ of Argentinean shoreline (SW Atlantic: From 38S to 54S). Marine Pollution Bulletin, 58(5), 695-701.

Burnham, K. P., \& Anderson, D. R. (2002). Information and likelihood theory: a basis for model selection and inference. Model selection and multimodel inference: a practical information-theoretic approach, 2, 49-97.

Cahalan, J. A., Siddall, S. E., \& Luckenbach, M. W. (1989). Effects of flow velocity, food concentration and particle flux on growth rates of juvenile bay scallops Argopecten irradians. Journal of Experimental Marine Biology and Ecology, 129(1), 45-60.

Chomnalez, F. (2011) Evolución geomorfológica del área costera de Las Grutas, provincia de Río Negro (19692008). Párrafos geográficos, 10(1), 116-146.

Clark, A. M., \& Downey, M. E. (1992). Starfishes of the Atlantic. Chapman \& Hall, London.

Collins, M., Knutti, R., Arblaster, J., Dufresne, J. L., Fichefet, T., Friedlingstein, P., ... \& Shongwe, M. (2013). Long-term climate change: projections, commitments and irreversibility.

Dias, J. F., Fernandez, W. S., Boufleur, L. A., Dos Santos, C. E. I, Amaral, L., \& Yoneama, M. L. (2009). Biomonitoring study of seasonal anthropogenic influence at the Itamambuca beach (SP, Brazil). Nuclear Instruments and Methods in Physics Research B, 267, 1960-1964.

Dupont, S., Ortega-Martínez, O., \& Thorndyke, M. (2010). Impact of near-future ocean acidification on echinoderms. Ecotoxicology, 19, 449-462.

Escofet, A. M., Olivier, S. R., Orensanz, J. M., \& Scarabino Caravadossi, V. M. (1978). Biocenología bentónica del Golfo de San Matías (Río Negro, Argentina): Metodología, experiencias y resultados del estudio ecológico de un gran espacio geográfico en América Latina (No. DOC 0083).

Feder, H. M. (1970). Growth and predation by the ochre sea star, Pisaster ochraceus (Brandt), in Monterey Bay, California. Ophelia, 8, 161-185.

Flammang, P., Warnau, M., Temara, A., Lane, D. J., \& Jangoux, M. (1997). Heavy metals in Diadema setosum (Echinodermata, Echinoidea) from Singapore coral reefs. Journal of Sea Research, 38(1), 35-45.

Freeman, S. M., Richardson, C. A., \& Seed, R. (2001). Seasonal abundance, spatial distribution, spawning and growth of Astropecten irregularis (Echinodermata: Asteroidea). Estuarine, Coastal and Shelf Science, 53(1), 39-49.

Gagliardini, D. A., \& Rivas, A. L. (2004). Environmental characteristics of San Matías Gulf obtained from LANDSAT-TM and ETM+ data. Gayana (Concepción), 68(2), 186-193. 
Gaines, S. D., \& Bertness, M. (1993). The dynamics of juvenile dispersal: why field ecologists must integrate. Ecology, 74(8), 2430-2435.

Gerhardt, A. (1992). Effects of subacute doses of iron (Fe) on Leptophlebia marginata (Insecta: Ephemeroptera). Freshwater Biology, 27(1), 79-84.

Gil, D. G., \& Zaixso, H. E. (2007). The relation between feeding and reproduction in Anasterias minuta (Asteroidea: Forcipulata). Marine Biology Research, 3(4), 256-264.

Gil, D. G., \& Zaixso, H. E. (2008). Feeding ecology of the subantarctic sea star Anasterias minuta within tide pools in Patagonia, Argentina. Revista de Biología Tropical, 56(3), 311-328.

Gil, D. G., Escudero, G., \& Zaixso, H. E. (2011). Brooding and development of Anasterias minuta (Asteroidea: Forcipulata) in Patagonia, Argentina. Marine Biology, 158, 2589-2602.

Grueber, C. E., Nakagawa, S., Laws, R. J., \& Jamieson, I. G. (2011). Multimodel inference in ecology and evolution: challenges and solutions. Journal of Evolutionary Biology, 24(4), 699-711.

Hamel, J. F., \& Mercier, A. (1995). Prespawning behavior, spawning, and development of the brooding starfish Leptasterias polaris. The Biological Bulletin, $188(1), 32-45$.

Harley, C. D. G. (2011). Climate change, keystone predation, and biodiversity loss. Science, 334, 1124-1127.

Harley, C. D. G., Hughes, A. R., Hultgren, K. M., Miner, B. G., Sorte, C. J. B., Thornber, C. S., Rodriguez, L. F., Tomanek, L., \& Williams, S. L. (2006). The impacts of climate change in coastal marine systems. Ecology Letters, 9, 228-241.

Hernández, D. A., \& Tablado, A. (1987). Asteroidea de Puerto Deseado (Santa Cruz, Argentina) 1. Studies on neotropical fauna and environment, 22(3), 155-166.

Iribarne, O. O. (1990). Use of shelter by the small Patagonian octopus Octopus tehuelchus: availability, selection and effects on fecundity. Marine Ecology Progress Series, 66, 251-258.

Jones, C. G., Lawton, J. H., \& Shachak, M. (1994). Organisms as ecosystem engineers. In Ecosystem management (pp. 130-147). Springer New York.

Keppel, E. A., Scrosati, R. A., \& Courtenay, S. C. (2015). Interactive effects of ocean acidification and warming on subtidal mussels and sea stars from Atlantic Canada. Marine Biology Research, 11(4), 337-348.

Kobayashi, N., \& Okamura, H. (2005). Effects of heavy metals on sea urchin embryo development. Part 2. Interactive toxic effects of heavy metals in synthetic mine effluents. Chemosphere, 61(8), 1198-1203.
Kokot, R. R., Codignotto, J. O., \& Elissondo, M. (2004). Vulnerabilidad al ascenso del nivel del mar en la costa de la provincia de Río Negro. Revista de la Asociación Geológica Argentina, 59, 477-487.

Larsson, B. A. (1968). Scuba-studies on vertical distribution of Swedish rocky-bottom echinoderms. A methodological study. Ophelia, 5(1), 137-156.

Lawrence, J. M. (2010). Energetic costs of loss and regeneration of arms in stellate echinoderms. Integrative and comparative biology, 50(4), 506-514.

Mercier, A., \& Hamel, J. F. (2008). Depth-related shift in life history strategies of a brooding and broadcasting deep-sea asteroid. Marine Biology, 156(2), 205.

Mercier, A., \& Hamel, J. F. (2009). Endogenous and exogenous control of gametogenesis and spawning in echinoderms. Advances in Marine Biology, 55, 1-302.

Moreira, D., Simionato, C. G., Dragani, W. C., \& Nuandñez, M. N. (2009). Tidal and residual currents observations at the San Matías and San José gulfs, Northern Patagonia, Argentina. Journal of Coastal Research, 957-968.

Morsan, E. M. (2009). Impact on biodiversity of scallop dredging in San Matías Gulf, northern Patagonia (Argentina). Hydrobiologia, 619(1), 167-180.;

Morsan, E., Zaidman, P., Ocampo-Reinaldo, M. \& Ciocco, N. (2010). Population structure, distribution and harvesting of southern geoduck, Panopea abbreviata, in San Matías Gulf (Patagonia, Argentina). Scientia Marina, 74(4), 763-772.;

Narvarte, M., González, R., \& Filippo, P. (2007). Artisanal mollusk fisheries in San Matías Gulf (Patagonia, Argentina): An appraisal of the factors contributing to unsustainability. Fisheries Research, 87(1), 68-76.

Navarrete, S. A., \& Castilla, J. C. (2003). Experimental determination of predation intensity in an intertidal predator guild: dominant versus subordinate prey. Oikos, 100, 251-262.

Pérez, A. F., Boy C. C., Calcagno J., \& Malanga G. (2015). Reproduction and oxidative metabolism in the brooding sea star Anasterias antarctica (Lütken, 1957). Journal of Experimental Marine Biology and Ecology, 463, 150-157.

Ramírez, F. C. (1996). Composición, abundancia y variación estacional del zooplankton de red del Golfo San Matías. Frente Marítimo, 16, 157-167.

Saier, B. (2001). Direct and indirect effects of seastars Asterias rubens on mussel beds (Mytilus edulis) in the Wadden Sea. Journal of Sea Research, 46(1), 29-42.

Salvat, M. B. (1985). Biología de la reproducción de Anasterias minuta Perrier (Echinodermata, Asteroidea): Especie incubadora de las costas patagónicas 
(Doctoral dissertation, Facultad de Ciencias Exactas y Naturales. Universidad de Buenos Aires).

Smith, G. F. M. (1940). Factors limiting distribution and size in the starfish. Journal of the Fisheries Board of Canada, 5(1), 84-103.

Temara, A., Warnau, M., Jangoux, M., \& Dubois, P. (1997). Factors influencing the concentrations of heavy metals in the asteroid Asterias rubens L. (Echinodermata). Science of the total environment, 203(1), 51-63.

Tokeshi, M., Estrella, C., \& Paredes, C. (1989). Feeding ecology of a size-structured predator population, the South American sun-star Heliaster helianthus. Marine Biology, 100(4), 495-505.

Trieff, N. M., Romaña, L. A., Esposito, A., Oral, R., Quiniou, F., Iaccarino, M., Alcock, N., Ramanujam, V. M. S., \& Pagano, G. (1995). Effluent from bauxite factory induces developmental and reproductive damage in sea urchins. Archives of Environmental Contamination and Toxicology, 28(2), 173-177.

Wootton, J. T., Pfister, C. A., \& Forester, J. D. (2008). Dynamic patterns and ecological impacts of declining ocean $\mathrm{pH}$ in a high-resolution multi-year dataset. Proceedings of the National Academy of Sciences, 105(48), 18848-18853.

Young, C. M., Tyler, P. A., Cameron, J. L., \& Rumrill, S. G. (1992). Seasonal breeding aggregations in low-density populations of the bathyal echinoid Stylocidaris lineata. Marine Biology, 113(4), 603-612.

Zuur, A. F., Ieno, E. N., Walker, N. J., Saveliev, A. A., \& Smith, G. M. (2009). Mixed effects models and extensions in ecology with R. Gail M, Krickeberg K, Samet JM, Tsiatis A, Wong W, editors. New York, NY: Spring Science and Business Media. 